\title{
Analysis of instability of tall buildings with prestressed and waffle slabs
}

\section{Análise da instabilidade de edifícios altos com lajes protendidas e lajes nervuradas}

V. M. PASSOS a vmelopassos@gmail.com

L. A. FEITOSA leofeitosa@gmail.com

E. C. ALVES elcio.calves1@gmail.com

M. S. AZEVEDO a macksuel.azevedo@gmail.com

\begin{abstract}
The construction system of prestressed flat slabs has been gaining market in Brazil, since it eliminates the use of beams, allows you to perform structures under coluns by area and reduces the cycle of concrete slabs. Thus the analysis of global stability of buildings, takes into account the effects of 2nd order, and these additional effects to the structure obtained from the deformation thereof, calculated by the iterative method P-Delta. The Brazilian ABNT NBR 6118: 2014 [2] assesses the overall stability of reinforced concrete structures through practical parameters, which are the parameter $\alpha$ (Alpha) and $\gamma_{z}$ (Gamma z) coefficient. In this research we seek to study the global stability of slender buildings consist of flat slabs, with slenderness (ratio of the smaller width with the height of the building) approximately one to six, from the modeling of a building with prestressed slabs nonadherent and waffle slabs. To model will use the commercial software CAD / TQS.
\end{abstract}

Keywords: global stability, analysis of 2nd order, gamma z, p-delta.

\section{Resumo}

O sistema construtivo de lajes planas protendidas vem ganhando mercado no Brasil, pois dispensa o uso de vigas, permite executar estruturas com menos pilares por área e reduz o ciclo de concretagem das lajes. Assim a análise de estabilidade global de edificações, leva em consideração os efeitos de $2^{a}$ ordem, sendo estes efeitos adicionais à estrutura obtidos a partir das deformações da mesma, calculadas pelo método iterativo P-Delta. A norma brasileira ABNT NBR 6118:2014 [2] avalia a estabilidade global de estruturas de concreto armado através de parâmetros práticos, sendo estes o parâmetro $\alpha$ (alfa) e o coeficiente $\gamma_{z}$ (gama z). Nesta pesquisa busca-se estudar a estabilidade global de edificações esbeltas compostas por lajes planas, com ordem de esbeltez (relação da menor largura com a altura da edificação) de um para seis, a partir da modelagem de uma edificação com lajes protendidas não-aderentes e lajes nervuradas. Para modelagem será utilizado o programa comercial CAD/TQS.

Palavras-chave: estabilidade global, análise de $2^{\mathrm{a}}$ ordem, gama z, p-delta.

Centro Tecnológico, Departamento de Engenharia Civil, Universidade Federal do Espírito Santo, Vitória, ES, Brasil. 


\section{Introduction}

Of the slab construction technologies that are used in the Brazilian market, prestressed flat and waffle slabs stand out for providing increased productivity and material savings compared to conventional slab and beam systems. Moreover, these slabs allow for larger spans, fewer formworks, better utilization of materials, and greater architectural flexibility.

Because of these advantages, a feasibility analysis of tall and slender buildings that use these types of construction systems is proposed in terms of the global stability of the structure.

The bracing in these types of buildings relies on the group of columns that are part of the buildings. Because the structure is devoid of beams, there is no a priori stabilization of the building by space frames.

In this case, it is common to use conveniently positioned " $\mathrm{U}$ " or " $\mathrm{L}$ " shaped column-walls to ensure the required stiffness in both directions for stability. Prestressed slabs have a minimum thickness of sixteen centimeters (Item 13.2.4.1 of ABNT NBR 6118:2014 [2]), but it is common to use thicknesses of at least eighteen centimeters to ensure the stiff diaphragm effect and the bracing of columns, which guarantee that all of the components work together to stabilize the structure. The greater thickness in the region where the waffle slabs connect to the columns makes this location sufficiently stiff to stabilize the building.

This study evaluates the influence of variations in several parameters on the global stability of the proposed structure, including the slab thickness, the column section, the coefficients that represent the physical nonlinearity of the structural elements, the height of the typical floor plan and the characteristic strength of the concrete.

\subsection{Objectives}

The aim of this research is to analyze different models for buildings with slenderness ratios of one to six by varying the type of slab construction system that is used between prestressed slabs and waffle slabs. Thus, this study will evaluate the instability parameters of the structure that result from variations of several general parameters, such as the thickness of the slabs, the sections of the columns, the coefficients that represent the physical nonlinearity of structural elements, the height of the typical floor plan and the characteristic strength of the concrete.

The commercial software CAD/TQS version 17.11.8 is used to analyze and test these instability parameters.

\section{Literature review}

\subsection{Nonlinear analysis}

Reinforced concrete structures display important nonlinear behavior, which is a result of the nonlinear relationships between the forces and displacements that result from physical and geometric nonlinearities. Such behavior is inherent in all reinforced concrete structures and must be taken into account during structural analyses.

The physical nonlinearity of reinforced concrete is generated because it consists of materials with different physical properties that create an anisotropic, heterogeneous material with an elastic mod- ulus that varies at each point of the stress-strain diagram curve. In addition, the difference between the compressive strength and tensile strength of concrete is large. In applications, this difference leads to the formation of cracks by tension, which reduces the bearing capacity of the parts. In addition to cracking, creep, the combination of different forces, and the presence of rebar also generate nonlinear behavior in the concrete.

ABNT NBR 6118:2014 [2] uses a simplification to consider this physical nonlinearity. The stiffnesses of the structural elements are modified using reduction coefficients for each type of element (beams, columns and slabs) according to the influence that the element has on the global stability of the structure. A stiffness that is reduced by a coefficient is called the effective stiffness or the secant stiffness.

The aforementioned standard requires the physical nonlinearity to be considered and proposes values that should be adopted to reduce the stiffnesses of the structural elements, namely:

Slabs: $(\mathrm{El})_{\mathrm{sec}}=0,3 \mathrm{E}_{\mathrm{ci}} \mathrm{I}_{\mathrm{c}}$

Beams:

$-(E I)_{\sec }=0,4 E_{c i c}$ para $A_{s}^{\prime} \neq A_{s}$

$-(E I)_{\text {sec }}=0,5 E_{c i c}{ }_{c}$ para $A_{s}{ }^{\prime}=A_{s}$ Columns: $(\mathrm{EI})_{\mathrm{sec}}=0,8 \mathrm{E}_{\mathrm{ci}} \mathrm{I}$

where:

$\mathrm{I}_{\mathrm{c}}$ : moment of inertia of the gross concrete section;

$\mathrm{E}_{\mathrm{ci}}$ : modulus of the initial tangential strain of the concrete.

Item 15.7.3 of the previous version of the standard, ABNT NBR $6118: 2007$ [1], states that if the global instability factor $\gamma_{z}$ is less than 1.3 and the bracing structure of the building is only composed of columns and beams, the effective or secant stiffness of the columns and beams could be taken as:

- Columns and Beams: $(\mathrm{EI})_{\mathrm{sec}}=0,7 \mathrm{E}_{\mathrm{ci}} \mathrm{c}$

However, this consideration is not included in the new 2014 version. Less cracking occurs in prestressed elements (slabs and beams) than in reinforced concrete elements. Thus, it would be interesting to study the use of reduction coefficients with higher values than those indicated by the current standard, or retaining the values from the previous version of the standard and the value of 0.7 for a prestressed slab, when a slab is used to resist the horizontal forces; i.e., when it is part of the global bracing system of the structure.

Even if a structure is built with a material that has a linear stressstrain relationship, it may exhibit nonlinear behavior when it experiences major displacements. The lateral strain of a structural component leads to the appearance of additional bending moments (second-order moments) due to the new location of the vertical force. This behavior is called geometric nonlinearity because it lacks a linear relationship between the forces and effects.

To perform a structural analysis that considers geometric nonlinearity, ABNT NBR 6118:2014 [2] uses a safety formula for the combination of actions. The actions are increased by the factor $g_{f} / g_{f 3}$, and the internal forces are then increased by the factor $g_{f 3}$, which is equal to 1.1 .

\subsection{Second-order effects}

The first-order structural analysis considers the structure in its undisturbed geometric configuration. When the deformed geometry of the structure is considered, additional forces, which are called second-order effects, are generated in the structural system; these 
additional effects on the structure are caused by its deformation and are responsible for the nonlinear behavior of the structure. One way to take into consideration this effect in the structure is the use of Iterative Method P-Delta (P- $\Delta$ ).

The iterative P-Delta method, which converts the lateral displacement into equivalent horizontal forces, is used in the second-order analysis of structures. The first-order analysis of a structure, which considers its undisturbed initial configuration, obtains the displacements, which will be the basis for the definition of "pseudo" horizontal loads that are equivalent to the second-order loading. In each step, new "pseudo" lateral forces are obtained, which tend to decrease as the structure reaches an equilibrium position. The iterations end when the effect of the "pseudo" load is small compared to the effect of the previous load or when is determined that the structure will cannot have global stability.

\subsection{Global stability}

The global stability of the structure is defined as its sensitivity to second-order effects and is an inversely proportional relationship in which the more sensitive the structure is to the second-order effects, the less stable it will be.

The Brazilian standard ABNT NBR 6118:2014 [2] does not require second-order forces to be considered if they are less than $10 \%$ of the first-order forces. Thus, it is always necessary to perform the second-order analysis regardless of whether these effects will be used to design the structure. The standard uses the gamma $Z\left(\gamma_{z}\right)$ coefficient and the alpha $(\alpha)$ parameter to assist in the decision to consider the second-order effects.

The $\gamma_{z}$ instability coefficient was introduced by Franco and Vasconcelos (1991) [5] and measures the sensitivity of the structure to second-order effects; it can also be used to increase the first-order effects from the horizontal loads to obtain the approximate secondorder effects. The $\gamma_{z}$ coefficient is defined by:

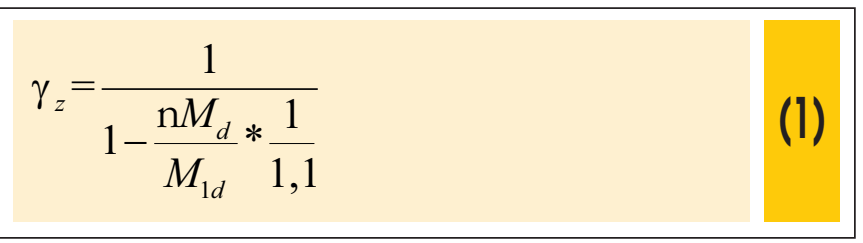

where:

$\Delta \mathrm{M}_{\mathrm{d}}$ : The sum of the products of all of the vertical forces that act on the structure by the horizontal displacements, which are obtained in the first-order analysis;

$M_{1 d}$ : The moment of tipping, which is the sum of the moments that are produced by the horizontal forces with respect to the base of the structure.

Feitosa e Alves (2014) [6] presents a study on the global instability of buildings with slenderness ratios of one to four with flat slabs. In this study it is presented the influence of the nonlinearity effect and impact on the instability coefficient.

\section{Figure 1 - Architecture and structure for the typical floor plan with prestressed slabs - Model 01/01}

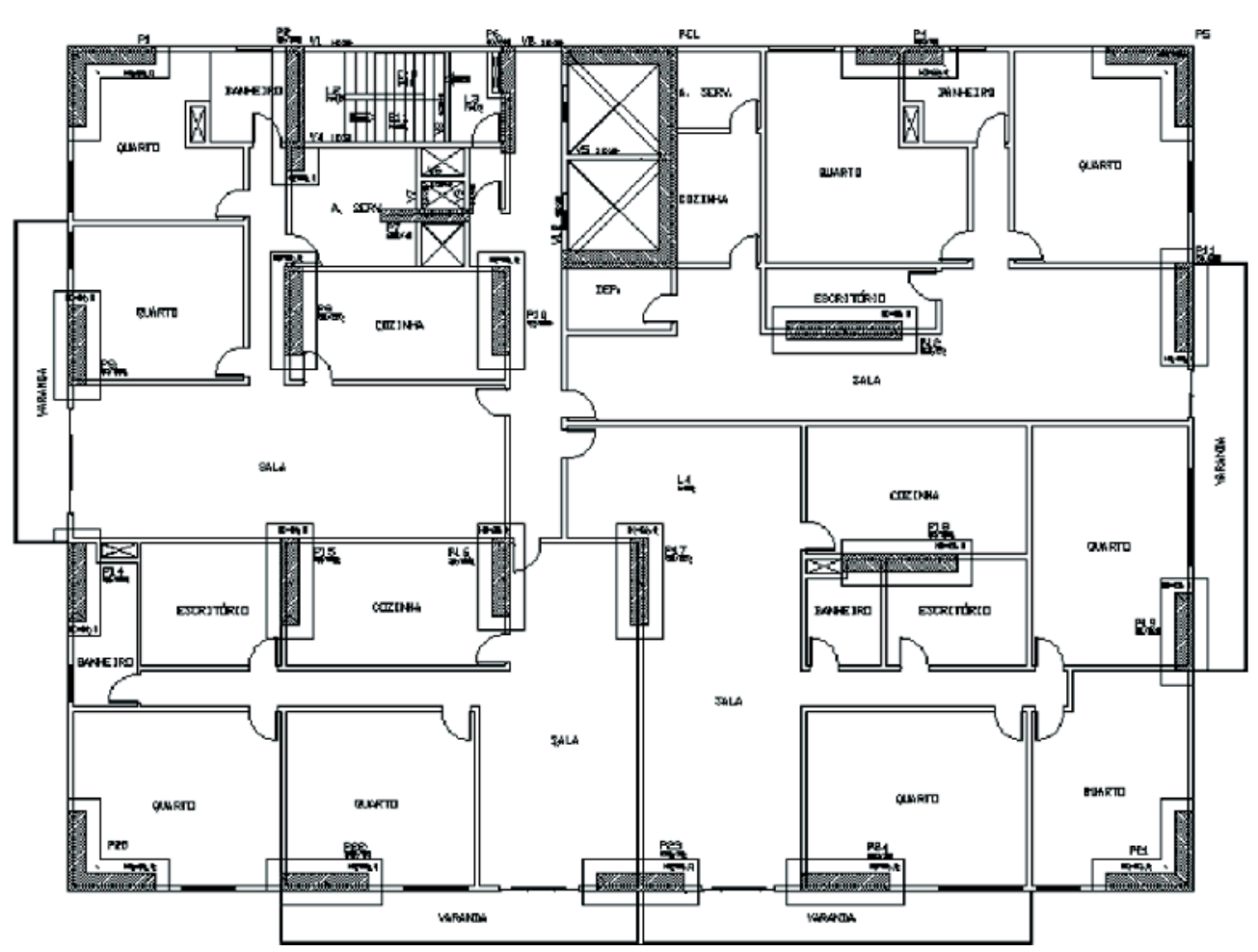




\subsection{Main factors that influence the global stability}

Of the factors that influence the global stability of buildings, the vertical loading and the stiffness of the structure are the most influential. The $\gamma_{z}$ parameter indicates this relevance in the formula because an increase in the vertical load increases the value of $\gamma_{z}$ for the same horizontal loading. A greater horizontal loading does not increase the value of $\gamma_{z}$ because the first- and second-order forces increase at the same rate; that is, $\Delta \mathrm{M}_{\mathrm{d}} / \mathrm{M}_{1 \mathrm{~d}}$ remains constant.

The stiffer the structure is, the smaller its displacements will be; this will generate lower second-order moments, which will reduce the $\gamma_{z}$ coefficient.

\section{Models}

The building models feature prestressed flat slabs or waffle slabs. Slenderness ratios of one to six were adopted, thus, a building width of 24 meters, which is measured from the edge of the corner column, gives a building height of 144 meters. This slenderness ratio includes the tower geometry but does not include the base of the building model. Based on an architectural plan with a geometrically-asymmetric design, the buildings were modelled using the CAD/TQS software to evaluate the influence of the parameters based on the $\gamma_{z}$ instability parameter and lateral displacements.

\subsection{Analysis model VI - CAD/TQS}

Model VI simulates the building as a single frame that is composed of elements that simulate the slabs, beams and columns of the structure. The slabs contribute strength to resist wind forces along with the beams and columns. The connections between the beams and columns are regarded as semi-rigid.

\subsection{Considering P-Delta in CAD/TQS}

TQS Informática LTDA developed a coefficient called RM2M1 to represent the intensity of the second-order forces relative to the first-order forces. The second-order forces are calculated using the iterative P-Delta method. RM2M1 is given by:

$$
\mathrm{RM} 2 \mathrm{M} 1=1+\frac{\mathrm{M}_{2}}{M_{1}}
$$

where:

$M_{1}$ : The moment of the horizontal forces with respect to the base of the building;

$M_{2}$ : The sum of the vertical forces multiplied by the displacement of the nodes of the structure due to the nonlinear combination of horizontal forces from the P-Delta calculation.

\subsection{Description of models}

The building shown in Figure 1 was modelled with a flat slab, and the cross section of the columns was varied until it reached a value similar to the $\gamma_{z}$ coefficient limit that is recommended by ABNT NBR 6118:2014 [2]. This model, which is called 01/01, was the basis for

\section{Figure 2 - 3D - Typical floor plan with prestressed slabs - Model 01/01}

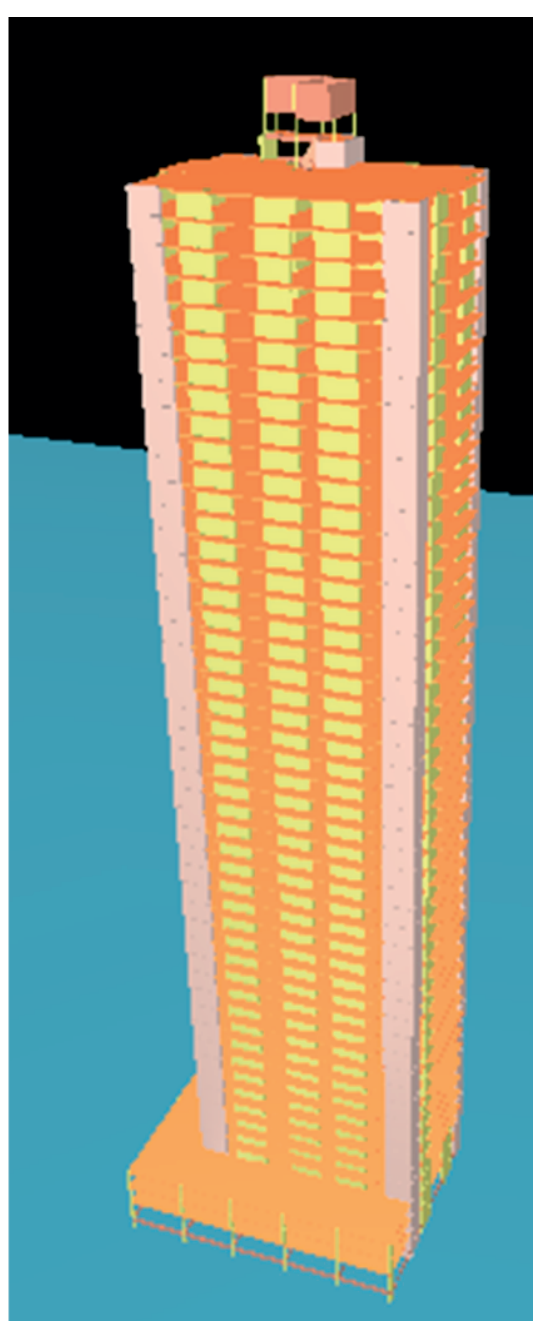

the subsequent models and resulted in a value of $\gamma_{z}$ of 1.297 (wind $\left.90^{\circ}-270^{\circ}\right)$. The Figures 2 and 3 show $3 \mathrm{D}$ details of building. In model 01/02, the thickness of the lift column (stiff core) was changed to assess whether a higher stiffness would lead to a significant reduction in the value of $\gamma_{z}$.

In model $01 / 03$, the thickness of the slab was increased because in model VI takes into account the effect of the transverse bending stiffness of the slabs on the frame. Thus, the slabs begin to contribute to resisting the horizontal forces. Therefore, increasing the thickness of the slab would increase the stiffness of the bracing system. The increased weight due to the increased thickness of the slab would be offset by its increased stiffness, as stated FEITOSA and ALVES (2015) [6].

In model 01/04, the ceiling height of the typical floor plan was decreased, which increased the frame stiffness due to the decrease in the length of the unbraced columns. 


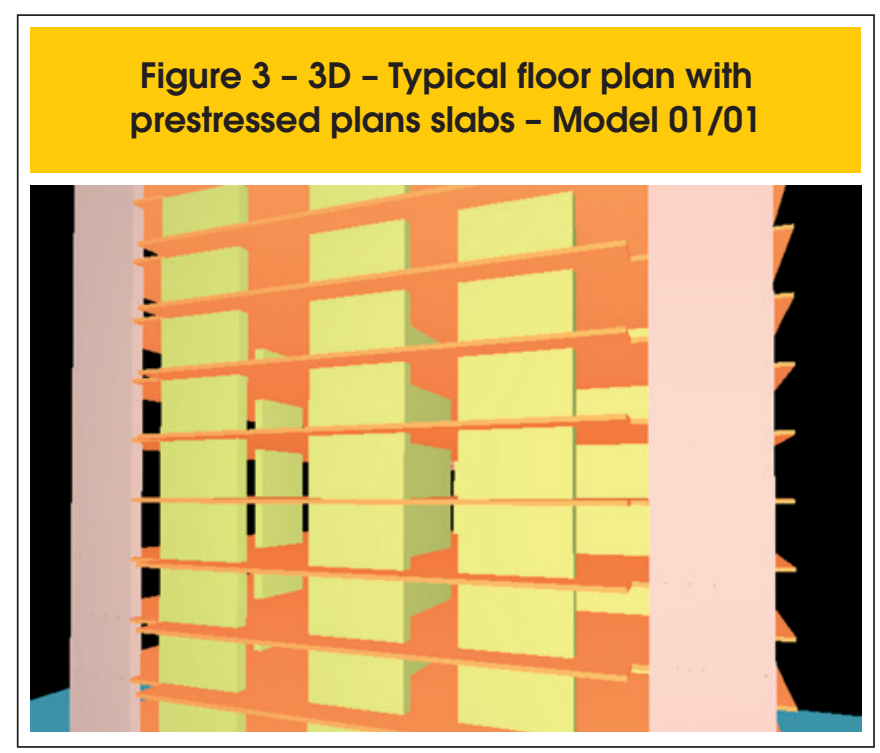

As stated previously, prestressed slabs and beams experience less cracking than reinforced concrete slabs and beams. Thus, the values of the coefficients that represent the physical nonlinearity of these elements were increased in model 01/05.

Finally, model 01/06 considered all of the changes from the previous models to decrease the section of the columns and evaluate the reduction of the amount of concrete used for the columns relative to the total amount of concrete used in the structure. The data for the model with the flat slabs are presented in Table 1.

The Model 02/01 is based on model 01/01, but the construction method was changed to waffle slabs as shown in Figures 4, 5 and 6 . The formworks were sixteen centimeters high, and the cover was five centimeters thick. The cross section of the columns was varied, and the model resulted in a $\gamma_{z}$ value of 1.297 (wind $90^{\circ}$ $270^{\circ}$ ). The Figures 5 and 6 show 3D details of building.

The changes in models 02/02, 02/03 and 02/04 were the same as those that were made in the models with the prestressed slabs. The changes in the coefficients that represent the physical nonlinearity were not implemented because of the absence of prestressed elements in the waffle slab models.

In model $02 / 05$, the cross sections of the columns were decreased as much as possible while keeping the $\gamma_{z}$ coefficient below the limit that is recommended by the standard. The data for the waffle slab models are presented in Table 2.

\section{Results and discussions}

\subsection{Analysis results of models 01/01 to 01/06}

The results obtained using the proposed design shown in Figure 1 and the models described above were analyzed and are shown in Tables 3, 4 and 5.

Figure 4 - Architecture and structure for a typical floor plan with waffle slabs - Model 02/01

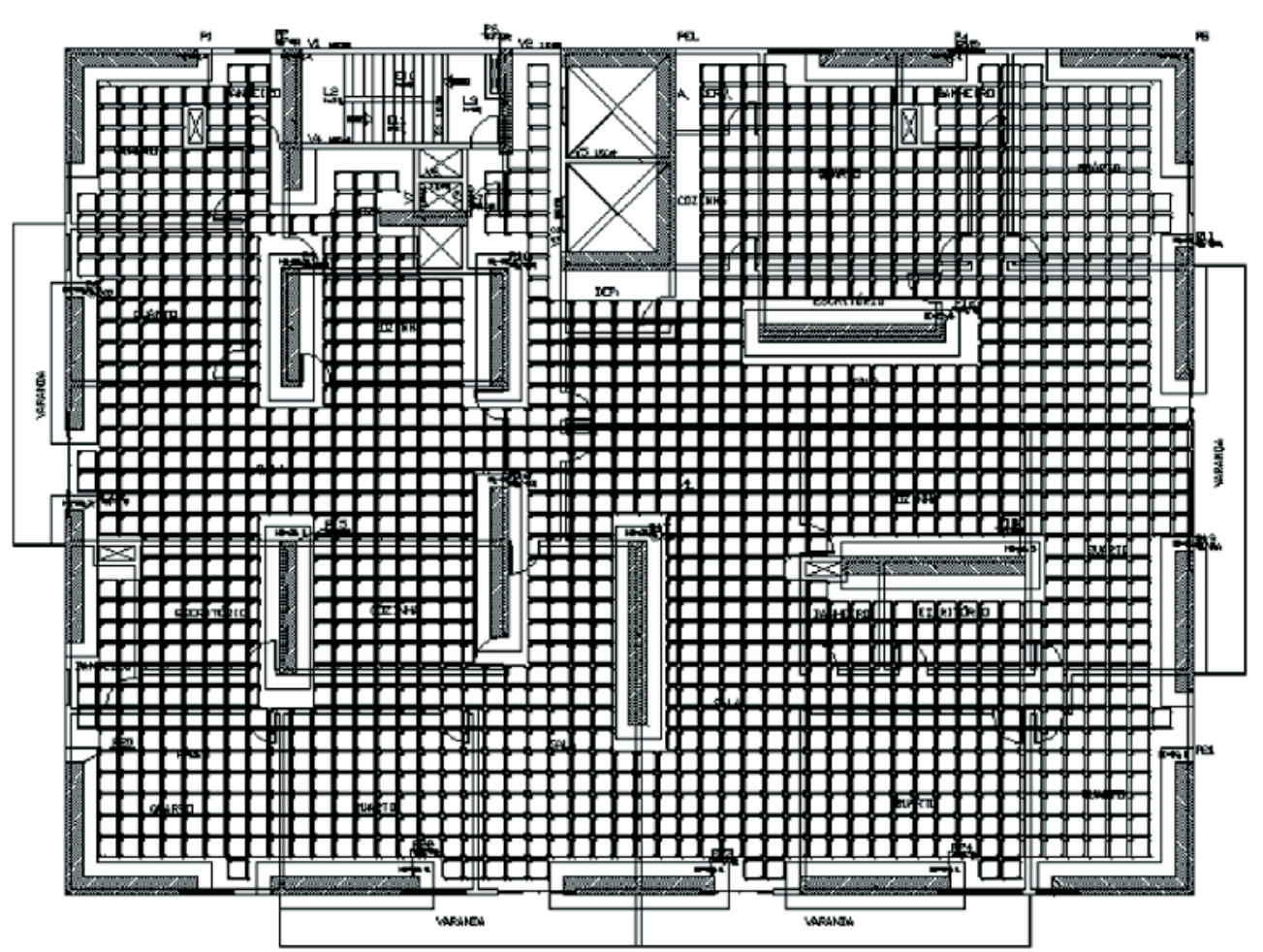


Figure 5 - 3D - Typical floor plan with waffle slabs - Model 02/01

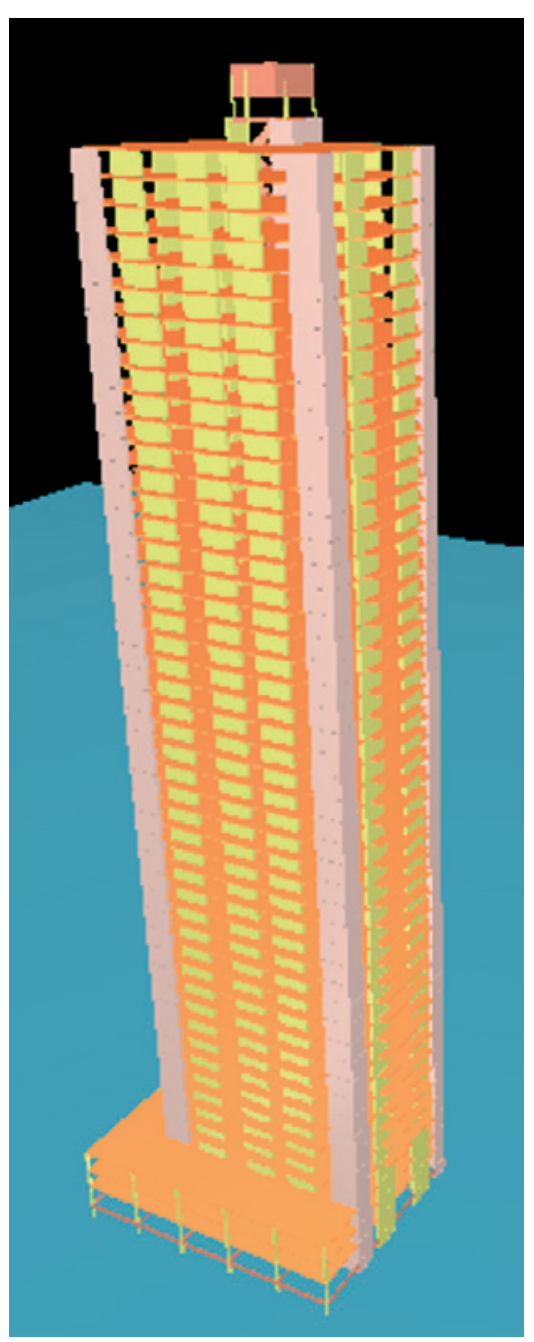

\section{Figure 6 - 3D - Typical floor plan with details of waffle slabs -Model 02/01}

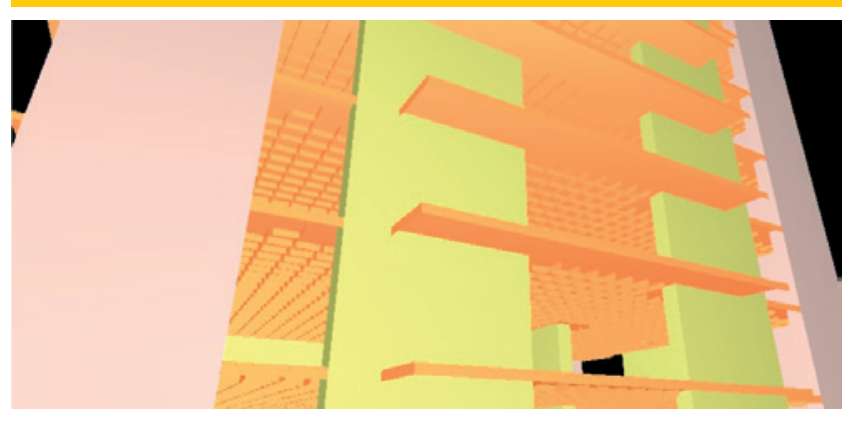

Increasing the thickness of the lift column (stiff core) in model $01 / 02$ did not cause a significant reduction in the $\gamma_{z}$ coefficient; the reductions were approximately $0.617 \%$ (wind $90^{\circ}-270^{\circ}$ ) and $0 \%$ (wind $0^{\circ}-180^{\circ}$ ).

The increase in slab thickness that was considered in model 01/03 reduced the $\gamma_{z}$ instability coefficient by approximately $4.472 \%$ (wind $90^{\circ}-270^{\circ}$ ) and $4.111 \%$ (wind $0^{\circ}-180^{\circ}$ ). These reductions demonstrate the importance of considering the cross stiffness of the slab in the global stability of the structure.

Reducing the ceiling height of the floors in model $01 / 04$ reduced $\gamma_{z}$ by approximately $2.005 \%$ (wind $90^{\circ}-270^{\circ}$ ) and $2.213 \%$ (wind $0^{\circ}-180^{\circ}$ ).

The greatest reduction in the $\gamma_{z}$ instability coefficient was obtained in model $01 / 05$, which considers the largest values of the physical nonlinearity coefficients; the reductions were approximately $9.368 \%$ with wind directions of $90^{\circ}-270^{\circ}$ and $8.142 \%$ with wind directions of $0^{\circ}-180^{\circ}$. These results confirm the possibility of extending the prestressed slabs, which increase the coefficient of physical nonlinearity when they are used in the bracing system of the structure because of their cross stiffness.

In model 01/06, the sections of the columns were decreased while keeping the $\gamma_{z}$ coefficient below the limit that is recommended by ABNT NBR 6118:2014 [2]. Compared with model 01/01, model $01 / 06$ resulted in a reduction of approximately $37.5 \%$ in the volume of concrete used for the columns and a reduction of approximately $31.3 \%$ in the formworks used for the columns.

\begin{tabular}{|c|c|c|c|c|c|c|c|c|}
\hline \multicolumn{9}{|c|}{ Table 1 - Data for the prestressed slab models } \\
\hline \multirow{3}{*}{ Model } & \multicolumn{7}{|c|}{ Prestressed slab - data from models } & \multirow{3}{*}{$\begin{array}{l}\text { Ceiling heigh } \\
\text { for typical } \\
\text { floor plan (m) }\end{array}$} \\
\hline & \multirow{2}{*}{$\begin{array}{l}\text { Lift column } \\
\text { thickness } \\
\text { (cm) }\end{array}$} & \multicolumn{2}{|c|}{ Nonlinearity coefficient } & \multirow{2}{*}{$\begin{array}{l}\text { Slab thickness } \\
\text { (cm) }\end{array}$} & \multicolumn{3}{|c|}{$f_{c k}(M P a)$} & \\
\hline & & Slabs & Beams & & Slabs & Beams & Columns & \\
\hline $01 / 01$ & 40 & 0,3 & 0,4 & 18 & 30 & 30 & 40 & 3,24 \\
\hline $01 / 02$ & 50 & 0,3 & 0,4 & 18 & 30 & 30 & 40 & 3,24 \\
\hline $01 / 03$ & 40 & 0,3 & 0,4 & 20 & 30 & 30 & 40 & 3,24 \\
\hline $01 / 04$ & 40 & 0,3 & 0,4 & 18 & 30 & 30 & 40 & 2,88 \\
\hline $01 / 05$ & 40 & 0,7 & 0,7 & 18 & 30 & 30 & 40 & 3,24 \\
\hline $01 / 06$ & 50 & 0,7 & 0,7 & 20 & 30 & 30 & 40 & 2,88 \\
\hline
\end{tabular}




\begin{tabular}{|c|c|c|c|c|c|c|c|c|}
\hline \multicolumn{9}{|c|}{ Table 2 - Data for the waffle slab models } \\
\hline \multirow{3}{*}{ Model } & \multicolumn{7}{|c|}{ Wafile slab - data from models } & \multirow{3}{*}{$\begin{array}{l}\text { Ceiling height } \\
\text { for typical } \\
\text { floor plan }(\mathrm{m})\end{array}$} \\
\hline & \multirow{2}{*}{$\begin{array}{l}\text { Lift column } \\
\text { thickness } \\
\text { (cm) }\end{array}$} & \multicolumn{2}{|c|}{ Nonlinearity coefficient } & \multirow{2}{*}{$\begin{array}{l}\text { Slab thickness } \\
(\mathrm{cm})\end{array}$} & \multicolumn{3}{|c|}{$\mathrm{f}_{\mathrm{ck}}(\mathrm{MPa})$} & \\
\hline & & Slabs & Beams & & Slabs & Beams & Columns & \\
\hline $02 / 01$ & 40 & 0,3 & 0,4 & 21 & 30 & 30 & 40 & 3,24 \\
\hline $02 / 02$ & 50 & 0,3 & 0,4 & 21 & 30 & 30 & 40 & 3,24 \\
\hline $02 / 03$ & 40 & 0,3 & 0,4 & 23,5 & 30 & 30 & 40 & 3,24 \\
\hline $02 / 04$ & 40 & 0,3 & 0,4 & 21 & 30 & 30 & 40 & 2,88 \\
\hline $02 / 05$ & 50 & 0,3 & 0,4 & 23,5 & 30 & 30 & 40 & 2,88 \\
\hline
\end{tabular}

\section{Table 3 - Results from models 01/01 e 01/02}

\begin{tabular}{|c|c|c|c|c|}
\hline \multicolumn{5}{|c|}{ Model 01/01 } \\
\hline \multicolumn{3}{|c|}{ Instability coefficient } & \multicolumn{2}{c|}{ Service limit state - SLS } \\
\hline Wind & Gamma Z & Alpha & $\begin{array}{c}\text { Local } \\
\text { disp. }\end{array}$ & $\begin{array}{c}\text { Global } \\
\text { disp. }\end{array}$ \\
\hline $90^{\circ}-270^{\circ}$ & 1,297 & 1,262 & $0,12(2120)$ & $5,53(2734)$ \\
\hline $0^{\circ}-180^{\circ}$ & 1,265 & 1,186 & $0,09(2705)$ & $3,34(4521)$ \\
\hline
\end{tabular}

\begin{tabular}{|c|c|c|c|c|}
\hline \multicolumn{5}{|c|}{ Model 01/02 } \\
Wind & Gamma Z & Alpha & $\begin{array}{c}\text { Local } \\
\text { disp. }\end{array}$ & $\begin{array}{c}\text { Global } \\
\text { disp. }\end{array}$ \\
\hline \begin{tabular}{|c|c|c|c|} 
Instability coefficient \\
$90^{\circ}-270^{\circ}$
\end{tabular} & 1,289 & 1,254 & $0,12(2142)$ & $5,39(2805)$ \\
\hline $0^{\circ}-180^{\circ}$ & 1,265 & 1,187 & $0,09(2695)$ & $3,32(4552)$
\end{tabular}

\begin{tabular}{|c|c|c|c|}
\hline \multicolumn{4}{|c|}{ RM2M1 - 1,330 } \\
\hline \multicolumn{4}{|c|}{ Quantity of columns } \\
\hline \multicolumn{2}{|c|}{ Concrete volume $\left(\mathrm{m}^{3}\right)$} & \multicolumn{2}{|c|}{ Area of formwork $\left(\mathrm{m}^{2}\right)$} \\
\hline Column & Total & Column & Total \\
\hline 8561,9 & 15121,7 & 36795,4 & 74365,1 \\
\hline \multicolumn{2}{|c|}{ Concrete volume rate } & \multicolumn{2}{|c|}{ Area of formwork rate } \\
\hline
\end{tabular}
$56,62 \%$

\begin{tabular}{|c|c|c|c|}
\hline \multicolumn{4}{|c|}{ RM2M1 - 1,324 } \\
\hline \multicolumn{4}{|c|}{ Quantity of columns } \\
\hline \multicolumn{2}{|c|}{ Concrete volume $\left(\mathrm{m}^{3}\right)$} & \multicolumn{2}{|c|}{ Area of formwork $\left(\mathrm{m}^{2}\right)$} \\
\hline Column & Total & Column & Total \\
\hline 8725,5 & 15284,1 & 36735,6 & 74322,2 \\
\hline \multicolumn{2}{|c|}{ Concrete volume rate } & \multicolumn{2}{|c|}{ Area of formwork rate } \\
\hline
\end{tabular}

$57,09 \%$

$49,43 \%$

\section{Table 4 - Results from models 01/03 e 01/04}

\begin{tabular}{|c|c|c|c|c|}
\hline \multicolumn{5}{|c|}{ Model $01 / 03$} \\
\hline Instability coefficient & Service limit state - SLS \\
\hline Wind & Gamma Z & Alpha & $\begin{array}{c}\text { Local } \\
\text { disp. }\end{array}$ & $\begin{array}{c}\text { Global } \\
\text { disp. }\end{array}$ \\
\hline $90^{\circ}-270^{\circ}$ & 1,239 & 1,141 & $0,12(2662)$ & $4,45(3399)$ \\
\hline $0^{\circ}-180^{\circ}$ & 1,213 & 1,069 & $0,07(3452)$ & $2,66(5683)$ \\
\hline
\end{tabular}

\begin{tabular}{|c|c|c|c|c|}
\hline \multicolumn{5}{c|}{ Model $\mathbf{0 1 / 0 4}$} \\
Wind & Gamma Z & Alpha & $\begin{array}{c}\text { Service limit state - SLS } \\
\text { Local }\end{array}$ & $\begin{array}{c}\text { Global } \\
\text { disp. }\end{array}$ \\
\hline $90^{\circ}-270^{\circ}$ & 1,271 & 1,216 & $0,11(2449)$ & $4,74(3146)$ \\
\hline $0^{\circ}-180^{\circ}$ & 1,237 & 1,128 & $0,08(3226)$ & $2,76(5399)$
\end{tabular}

\begin{tabular}{|c|c|c|c|}
\hline \multicolumn{4}{|c|}{ RM2M1 - 1,277 } \\
\hline \multicolumn{4}{|c|}{ Quantity of columns } \\
\hline \multicolumn{2}{|c|}{ Concrete volume $\left(\mathrm{m}^{3}\right)$} & \multicolumn{2}{|c|}{ Area of formwork $\left(m^{2}\right)$} \\
\hline Column & Total & Column & Total \\
\hline 8561,9 & 15744,2 & 36765,4 & 74353,3 \\
\hline \multicolumn{2}{|c|}{ Concrete volume rate } & \multicolumn{2}{|c|}{ Area of formwork rate } \\
\hline
\end{tabular}
$54,38 \%$

$$
49,45 \%
$$

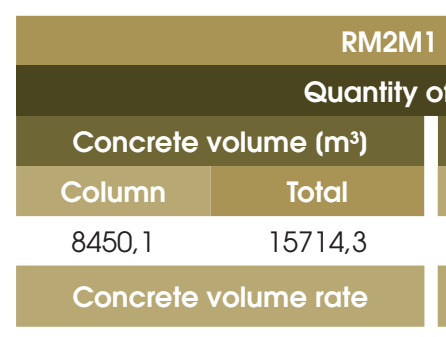

$53,77 \%$

\section{RM2M1 - 1,318}

Quantity of columns

\begin{tabular}{|c|c|}
\hline \multicolumn{2}{|c|}{ Area of formwork $\left(m^{2}\right)$} \\
\hline Column & Total \\
\hline 36230,0 & 77846,2 \\
\hline Area of & ork rate \\
\hline
\end{tabular}

$46,54 \%$ 


\section{Table 5 - Results from models 01/05 e 01/06}

\begin{tabular}{|c|c|c|c|c|}
\hline \multicolumn{5}{c|}{ Model 01/05 } \\
\hline \multicolumn{3}{|c|}{ Instability coefficient } & \multicolumn{2}{c|}{ Service limit state - SLS } \\
Wind & Gamma Z & Alpha & $\begin{array}{c}\text { Local } \\
\text { disp. }\end{array}$ & $\begin{array}{c}\text { Global } \\
\text { disp. }\end{array}$ \\
\hline $90^{\circ}-270^{\circ}$ & 1,172 & 0,976 & $0,10(3328)$ & $3,49(4336)$ \\
\hline $0^{\circ}-180^{\circ}$ & 1,162 & 0,953 & $0,06(5474)$ & $2,13(7113)$ \\
\hline
\end{tabular}

\begin{tabular}{|c|c|c|c|c|}
\hline \multicolumn{5}{|c|}{ Model 01/06 } \\
\hline \multicolumn{3}{|c|}{ Instability coefficient } & \multicolumn{2}{|c|}{ Service limit state - SLS } \\
\hline Wind & Gamma Z & Alpha & $\begin{array}{l}\text { Local } \\
\text { disp. }\end{array}$ & $\begin{array}{l}\text { Global } \\
\text { disp. }\end{array}$ \\
\hline $90^{\circ}-270^{\circ}$ & 1,275 & 1,178 & $0,12(2160)$ & $5,21(2859)$ \\
\hline $0^{\circ}-180^{\circ}$ & 1,298 & 1,110 & $0,16(1517)$ & 3,65 (4089) \\
\hline
\end{tabular}

\begin{tabular}{|c|c|c|c|}
\hline \multicolumn{4}{|c|}{ RM2M1 - 1,190 } \\
\hline \multicolumn{4}{|c|}{ Quantity of columns } \\
\hline \multicolumn{2}{|c|}{ Concrete volume $\left(\mathrm{m}^{3}\right)$} & \multicolumn{2}{|c|}{ Area of formwork $\left(\mathrm{m}^{2}\right)$} \\
\hline Column & Total & Column & Total \\
\hline 8561,9 & 15121,7 & 36765,4 & 74365,1 \\
\hline \multicolumn{2}{|c|}{ Concrete volume rate } & \multicolumn{2}{|c|}{ Area of formwork rate } \\
\hline
\end{tabular}

\begin{tabular}{|c|c|c|c|}
\hline \multicolumn{4}{|c|}{ RM2M1 - 1,357 } \\
\hline \multicolumn{4}{|c|}{ Quantity of columns } \\
\hline \multicolumn{2}{|c|}{ Concrete volume $\left(\mathrm{m}^{3}\right)$} & \multicolumn{2}{|c|}{ Area of formwork $\left(\mathrm{m}^{2}\right)$} \\
\hline Column & Total & Column & Total \\
\hline 5346,5 & 13420,7 & 25285,9 & 67476,4 \\
\hline \multicolumn{2}{|c|}{ Concrete volume rate } & \multicolumn{2}{|c|}{ Area of formwork rate } \\
\hline \multicolumn{2}{|c|}{$39,84 \%$} & \multicolumn{2}{|c|}{$37,47 \%$} \\
\hline
\end{tabular}

\subsection{Analysis results of models 02/01 to 02/05}

The results obtained using the proposed design shown in Figure 3 and models described above were analyzed and are shown in Tables 6, 7 and 8.

As in the model with the prestressed slabs, increasing the thickness of the lift columns (stiff core) in the model with the waffle slabs (model 02/02) did not significantly decrease the $\gamma_{z}$ coefficient; the reductions were approximately $0.694 \%$ (wind $90^{\circ}-270^{\circ}$ ) and $0 \%$ (wind $0^{\circ}-180^{\circ}$ ). Increasing the slab cover in model $02 / 03$ resulted in decreases of the $\gamma_{z}$ coefficient of approximately $3.392 \%$ (wind $90^{\circ}-270^{\circ}$ ) and $3.014 \%$ (wind $0^{\circ}-180^{\circ}$ ). The increase in weight due to the larger slab cover was offset by the greater stiffness as was discussed byFEITOSA and ALVES (2015) [6].

Decreasing the ceiling height of the floors in model 02/04 de-

creased the value of $\gamma_{z}$ by approximately $4.086 \%$ (wind $90^{\circ}-270^{\circ}$ ) and $3.632 \%$ (wind $0^{\circ}-180^{\circ}$ ).

Finally, decreasing the size of the columns in model $02 / 05$ caused a reduction of approximately $10.5 \%$ in the volume of concrete used for the columns and a reduction of approximately $6.22 \%$ in the formworks used for the columns compared to model 02/01. It is worth noting that the value of $\gamma_{z}$ in model $02 / 05$ is also less than the limit that is recommended by ABNT NBR 6118:2014 [2].

\section{Conclusões}

The analysis of models of prestressed slabs and waffle slabs showed that increasing the thickness of the lift columns (stiff core) did not significantly reduce the $\gamma_{z}$ instability coefficient.

Thicker prestressed slabs and a greater waffle slab cover

\section{Table 6 - Results from models 02/01 e 02/02}

\begin{tabular}{|c|c|c|c|c|}
\hline \multicolumn{4}{c|}{ Model 02/01 } \\
\hline Wind & Gamma Z & Alpha & $\begin{array}{c}\text { Lervice limit state - SLS } \\
\text { disp. }\end{array}$ & $\begin{array}{c}\text { Global } \\
\text { disp. }\end{array}$ \\
\hline $90^{\circ}-270^{\circ}$ & 1,297 & 1,280 & $0,14(1821)$ & $6,12(2470)$ \\
\hline $0^{\circ}-180^{\circ}$ & 1,294 & 1,249 & $0,12(2096)$ & $4,04(3758)$ \\
\hline
\end{tabular}

\begin{tabular}{|c|c|c|c|}
\hline \multicolumn{4}{|c|}{ RM2M1 - 1,345 } \\
\hline \multicolumn{4}{|c|}{ Quantity of columns } \\
\hline \multicolumn{2}{|c|}{ Concrete volume $\left(\mathrm{m}^{3}\right)$} & \multicolumn{2}{|c|}{ Area of formwork $\left(\mathrm{m}^{2}\right)$} \\
\hline Column & Total & Column & Total \\
\hline 8744,8 & 13362,8 & 37497,1 & 40303,7 \\
\hline \multicolumn{2}{|c|}{ Concrete volume rate } & \multicolumn{2}{|c|}{ Area of formwork rate } \\
\hline
\end{tabular}
$65,44 \%$

\begin{tabular}{|c|c|c|c|c|}
\hline \multicolumn{5}{|c|}{ Model 02/02 } \\
\hline \multicolumn{3}{|c|}{ Instability coefficient } & \multicolumn{2}{c|}{ Service limit state - SLS } \\
\hline Wind & Gamma Z & Alpha & $\begin{array}{c}\text { Local } \\
\text { disp. }\end{array}$ & $\begin{array}{c}\text { Global } \\
\text { disp. }\end{array}$ \\
\hline $90^{\circ}-270^{\circ}$ & 1,288 & 1,269 & $0,14(1851)$ & $5,94(2546)$ \\
\hline $0^{\circ}-180^{\circ}$ & 1,294 & 1,248 & $0,12(2097)$ & $4,01(3773)$ \\
\hline
\end{tabular}

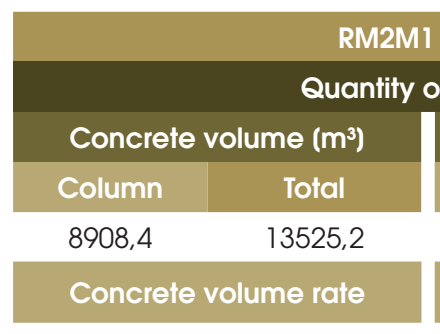

$65,87 \%$
RM2M1 - 1,335

Quantity of columns

\begin{tabular}{|lr|}
\hline \multicolumn{2}{|c|}{ Area of formwork $\left(\mathrm{m}^{2}\right)$} \\
\hline Column & Total \\
\hline 37467,3 & 40261,1 \\
\hline Area of formwork rate
\end{tabular}

$93,06 \%$ 
Table 7 - Results from Models 02/03 e 02/04

\begin{tabular}{|c|c|c|c|c|}
\hline \multicolumn{5}{c|}{ Model $\mathbf{0 2 / 0 3}$} \\
\hline \multicolumn{3}{|c|}{ Instability coefficient } & \multicolumn{2}{c|}{ Service limit state - SLS } \\
\hline Wind & Gamma Z & Alpha & $\begin{array}{c}\text { Local } \\
\text { disp. }\end{array}$ & $\begin{array}{c}\text { Global } \\
\text { disp. }\end{array}$ \\
\hline $90^{\circ}-270^{\circ}$ & 1,253 & 1,187 & $0,11(2187)$ & $5,14(2939)$ \\
\hline $0^{\circ}-180^{\circ}$ & 1,255 & 1,172 & $0,09(2704)$ & $3,39(4467)$ \\
\hline
\end{tabular}

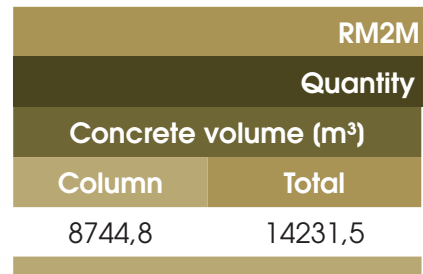

Concrete volume rate

$61,45 \%$

M2M1 - 1,299

\section{of columns}

\begin{tabular}{|l|l|}
\hline \multicolumn{2}{|c|}{ Area of formwork $\left(\mathrm{m}^{2}\right)$} \\
\hline Column & Total \\
\hline 37497,1 & 40287,8 \\
\hline
\end{tabular}

$93,07 \%$

significantly reduced the $\gamma_{z}$ coefficient. The greater vertical loads due to the thicker slabs are offset by the greater stiffness of the connections between the slabs and columns and also by the greater transverse bending stiffness. MARTINS (2001) [8] and FEITOSA and ALVES (2015) [6] obtained similar results.

Reducing the ceiling height between the floors in the models resulted in smaller $\gamma_{z}$ coefficients due to the shorter unbraced lengths of the columns.

The application of a higher coefficient to represent the physical nonlinearity in prestressed slabs significantly reduced the $\gamma_{z}$ coefficient; this reduction was the greatest of all of the models. Thus, it is interesting to study the use of higher values of the reduction coefficients than are indicated by the current standard given the lower amount of cracking that

\begin{tabular}{|c|c|c|c|c|}
\hline \multicolumn{5}{|c|}{ Table 8 - Results from Modelo 02/05 } \\
\hline \multicolumn{5}{|c|}{ Model 02/05 } \\
\hline \multicolumn{3}{|c|}{ Instability coefficient } & \multicolumn{2}{|c|}{ Service limit state - SLS } \\
\hline Wind & Gamma Z & Alpha & $\begin{array}{l}\text { Local } \\
\text { disp. }\end{array}$ & $\begin{array}{l}\text { Global } \\
\text { disp. }\end{array}$ \\
\hline $90^{\circ}-270^{\circ}$ & 1,285 & 1,251 & $0,12(2061)$ & $5,39(2768)$ \\
\hline $0^{\circ}-180^{\circ}$ & 1,291 & 1,216 & $0,10(2523)$ & $3,50(4260)$ \\
\hline \multicolumn{5}{|c|}{ RM2M1 - 1,355 } \\
\hline \multicolumn{5}{|c|}{ Quantity of columns } \\
\hline \multicolumn{2}{|c|}{ Concrete volume $\left(\mathrm{m}^{3}\right)$} & \multicolumn{3}{|c|}{ Area of formwork $\left(m^{2}\right)$} \\
\hline Column & Total & & Column & Total \\
\hline 7824,5 & 13904,5 & & 35163,9 & 38168,8 \\
\hline \multicolumn{2}{|c|}{ Concrete volume rate } & \multicolumn{3}{|c|}{ Area of formwork rate } \\
\hline \multicolumn{2}{|c|}{$56,27 \%$} & \multicolumn{3}{|c|}{$92,13 \%$} \\
\hline
\end{tabular}

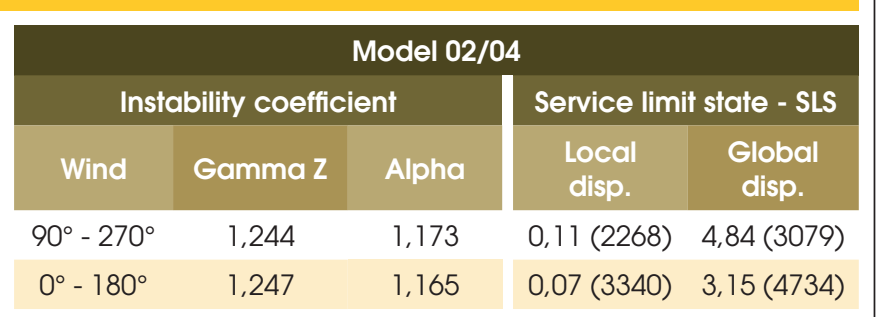

\begin{tabular}{|c|c|c|c|}
\hline \multicolumn{4}{|c|}{ RM2M1 - 1,283 } \\
\hline \multicolumn{4}{|c|}{ Quantity of columns } \\
\hline \multicolumn{2}{|c|}{ Concrete volume $\left(\mathrm{m}^{3}\right)$} & \multicolumn{2}{|c|}{ Area of formwork $\left(\mathrm{m}^{2}\right)$} \\
\hline Column & Total & Column & Total \\
\hline 8632,0 & 13747,2 & 36957,7 & 39985,7 \\
\hline \multicolumn{2}{|c|}{ Concrete volume rate } & \multicolumn{2}{|c|}{ Area of formwork rate } \\
\hline \multicolumn{2}{|c|}{$62,79 \%$} & \multicolumn{2}{|c|}{$92,43 \%$} \\
\hline
\end{tabular}

occurs in prestressed elements than in reinforced concrete elements. A comparison of the total volume of concrete used in models $01 / 06$ and $02 / 05$ revealed that model $01 / 06$ used approximately $3.5 \%$ less concrete than model 02/05. A similar comparison of the concrete volume of the columns shows that model 01/06 used approximately $31.6 \%$ less concrete for the columns. Thus, using a higher coefficient of physical nonlinearity for the prestressed slab makes this type of system competitive with waffle slabs in terms of the required volume of concrete for tall and slender buildings.

\section{References}

[1] ASSOCIAÇÃO BRASILEIRA DE NORMAS TÉCNICAS. NBR 6118: Projeto de estruturas de concreto - Procedimento. Rio de Janeiro, 2007.

[2] ASSOCIAÇÃO BRASILEIRA DE NORMAS TÉCNICAS. NBR 6118: Projeto de estruturas de concreto - Procedimento. Rio de Janeiro, 2014.

[3] BUENO, M.M.. Avaliação dos Parâmetros de Instabilidade Global em Estruturas de Concreto Armado. Dissertação de Mestrado, Universidade de Brasília, Brasília, 2009.

[4] EMERICK, A.A.. Projeto e Execução de Lajes Protendidas. Interciência, 2005.

[5] FRANCO, M.;VASCONCELOS,A.C.D.; Avaliação Prática dos Efeitos de $2^{\text {a }}$ Ordem em Edifícios Altos. Coloquiumonthe Rio CEB-FIP-ModelCode 90, Rio de Janeiro, 1991.

[6] FEITOSA, L.A.; ALVES, E.C..Study of global stability of tall buildings with prestressed slabs. Revista IBRACON de Estruturas e Materiais, v. 8, n. 2, p. 196-224, 2015.

[7] KIMURA, A.. Informática Aplicada em Estruturas de Concreto Armado. Pini, 2007.

[8] MARTINS,C.H.. Análise Não Linear de Estruturas Tridimensionais de Edifícios de Andares Múltiplos com Núcleo Resistentes, considerando a Rigidez Transversal à Flexão das Lajes. Tese de Doutorado, Universidade de São Paulo, São Carlos, 2001. 